\title{
PENEGAKAN HUKUM TERHADAP PELANGGARAN PROTOKOL KESEHATAN SEBAGAI UPAYA PENCEGAHAN VIRUS CORONA DI TINJAU DARI PERATURAN WALIKOTA LANGSA
}

\author{
Zuleha \\ Fakultas Hukum Universitas Samudra \\ Jl. Prof. Syarief Thayeb Hasan, Meurandeh, Langsa - Aceh \\ zuleha@unsam.ac.id
}

\begin{abstract}
The Langsa City Government has issued a policy regarding health protocols stipulated in Mayor Regulation Number 31 of 2020 concerning Application of Discipline and Health Protocol Enforcement. This is an effort to prevent and control the corona virus disease 2019 (Covid-9) in Langsa City. The research goal was to establish the legal arrangements for violators of the Health Protocol and government efforts against violators of the Health Protocol. The results of the study show that the Langsa City government has adopted a policy on health protocols regulated in Mayor Regulation Number 31 of 2020 on the application of discipline and Health Protocol Compliance in Langsa City to suppress the spread of the corona virus. The Langsa City Government's efforts to continue to urge and disseminate the dangers of the corona virus by raising public consciousness of following health protocols by using masks, maintaining distance and washing hands frequently in carrying out their activities
\end{abstract}

Keywords: Law Enforcement, Protocol on Hygiene, Corona Virus

\begin{abstract}
Abstrak
Pemerintah Kota Langsa telah mengeluarkan kebijakan mengenai protokol kesehatan yang diatur dalam Peraturan Walikota Nomor 31 Tahun 2020 tentang Penerapan Displin dan Penegakan Protokol Kesehatan. Hal itu sebagai upaya pencegahan dan pengendalian corona virus disease 2019 (Covid-9) di Kota Langsa. Tujuan Penelitian untuk mengetahui Pengaturan Hukum Terhadap Protokol Pelanggar Protokol Kesehatan dan Upaya Pemerintah Terhadap pelanggar Protokol Kesehatan. Hasil penelitian bahwa Di Kota Langsa dalam menekan penyebaran virus corona, pemerintah Kota Langsa telah menegluarkan kebijakan mengenai protokol kesehatan yang diatur dalam Peraturan Walikota Nomor 31 Tahun 2020 tentang Penerapan Displin dan Penegakan Protokol Kesehatan. Upaya pemerintah Kota Langsa tetap menghimbau dan melakukan sosialisasi bahayanya virus corona dengan menggugah kesadaran masyarakat untuk tetap mengikuti protokol kesehatan dalam menjalankan aktifitasnya dengan menggunakan menggunakan masker, jaga jarak dan sering mencuci tangan.
\end{abstract}

Kata Kunci : Penegakan Hukum, Protokol Kesehatan, Virus Corona 


\section{Pendahuluan}

Penegakan hukum ditujukan guna meningkatkan ketertiban dan kepastian hukum dalam masyarakat. Hal ini dilakukan antara lain dengan menertibkan fungsi, tugas dan wewenang lembaga-lembaga yang bertugas menegakkan hukum menurut proporsi ruang lingkup masing-masing, serta didasarkan atas sistem kerjasama yang baik dan mendukung tujuan yang hendak dicapai. ${ }^{1}$ Penegakan hukum menurut Jimly Asshiddiqie adalah proses dilakukannya upaya untuk tegaknya atau berfungsinya norma-norma hukum secara nyata sebagai pedoman perilaku dalam lalu lintas atau hubungan-hubungan hukum dalam kehidupan bermasyarakat dan bernegara. ${ }^{2}$

Menurut Laurensius dalam tulisannya menyatakan bahwa di dalam struktur kenegaraan modern, tugas penegakan hukum dijalankan oleh komponen eksekutif dan dilaksanakan oleh birokrasi dari eksekutif dan dilaksanakan oleh birokrasi dari eksekutif tersebut. ${ }^{3}$ Penegakan hukum itu sendiri tidak terlepas dari peran serta dari penegak hukum, karena penegak hukumlah yang nantinya menegakkan aturan hukum tersebut. Apabila penegak hukum mempunyai mental yang bobrok, maka akan menciptakan penegakan hukum mempunyai menciptakan penegakan hukum yang bobrok pula, begitu pula sebaliknya apabila penegak hukum mempunyai mental yang baik dalam menjalankan/ menegakkan aturan hukum yang baik dalam menjalankan hukum yang baik dan bersifat responsif. ${ }^{4}$

Sanyoto menambahkan lagi dalam jurnalnya Penegakan Hukum di Indonesia bahwa :

"Kajian secara sistematis terhadap penegakan hukum dan keadilan secara teoritis dinyatakan efektif apabila 5 pilar hukum berjalan baik yakni: instrument hukumnya,aparat penegak hukumnya, faktor warga masyarakatnya yang terkena lingkup peraturan hukum, faktor kebudayaan atau legal culture, faktor sarana dan fasilitas yang dapat mendukung pelaksanaan hukum".5

Selama masa pandemic-Covid 19 setiap orang diwajibkan untuk mematuhi protokol kesehatan ketika beraktifitas di luar rumah dengan menggunakan masker, jaga jarak dan cuci tangan. Penyebaran virus Corona tidak hanya menyerang kesehatan manusia, virus Corona baru juga mengakibatkan terpuruknya perekonomi negara-negara di dunia.

\footnotetext{
${ }^{1}$ Sanyoto, Penegakan Hukum di Indonesia, Jurnal Dinamika Hukum, Vol. 8 No. 3 September 2008, hlm. 199

2 Jimly Asshiddiqie, Penegakan Hukum, diakses www.jimly.com/makalah/namafile/56/ Penegakan_Hukum.pdf, hlm. . 1

${ }^{3}$ Laurensius Arliman S, Penegakan Hukum dan Kesadaran Masyarakat, (Yogyakarta: Deepublsih, 2015), hlm. 11

${ }^{4}$ Ibid., hlm. . 14

${ }^{5}$ Sanyoto, Op. Cit., hlm. 199
} 
Volume 16, Nomor 1, Januari - Juni 2021

Mengutip dari tulisan Sri Handayani Sagala, dkk, yang berjudul Hubungan Pengetahuan Dan Sikap Masyarakat Terhadap Covid-19: A Literature Review menuliskan bahwa "Pemahaman dan kesadaran masyarakat terhadap pencegahan Covid19 masih rendah. Selain itu tingkat kepatuhan masyarakat untuk melakukan social distance juga masih terlihat rendah, karena masih terlihat warga beraktivitas keluar rumah untuk tujuan rekreasi, duduk bergerombol, berkumpul tanpa menggunakan masker ataupun menjaga jarak, sehingga kemungkinan penyebaran masih menjadi tugas besar.Tindakan promotif untuk meningkatkan pemahaman masyarakat sangat diperlukan agar bisa meningkatkan pengetahuan mereka tentang isolasi mandiri yang sesuai standar operasional prosedur". 6

Protokol kesehatan adalah aturan dan ketentuan yang perlu diikuti oleh segala pihak agar dapat beraktivitas secara aman pada saat pandemi COVID-19 ini. Protokol kesehatan dibentuk dengan tujuan agar masyarakat tetap dapat beraktivitas secara aman dan tidak membahayakan keamanan atau kesehatan orang lain. Masyarakat yang disiplin mengikuti segala aturan yang tertera di dalam protokol kesehatan, maka penularan COVID-19 dapat diminimalisir. Protokol kesehatan terdiri bari beberapa macam, seperti pencegahan dan pengendalian. Penerapan protokol kesehatan menjadi kunci penting pencegahan penyebaran COVID-19. Cara penerpan yang efektif bisa dimulai dari kedisiplinan di dalam rumah, terutama jika salah satu anggota keluarga aktif beraktifitas di luar rumah. Kesadaran dan peran seluruh anggota keluarga untuk saling melindungi satu sama lain dengan menerapkan protokol pencegahan penyebaran COVID-19 sangatlah penting, dan akan terbiasa dalam pergaulan di masyarakat luas, sehingga dalam menjalankan protocol Kesehatan sudah menjadi displin dan kesadaran masyarakat dalam aktivitas kehidupan sehari-hari.

Berdasarkan tulisan Lukman Isnawan yang berjudul Pentingnya Kesadaran Masyarakat Dalam Memutuskan Rantai Penularan Covid-19 bahwa:

"Covid-19 atau dikenal dengan virus Corona merupakan salah satu wabah penyakit yang menjadi ancaman bagi umat manusia, virus yang awal munculnya berasal dari China tepatnya di Wuhan, pada penghujung tahun 2019. Organisasi Kesehatan Dunia (WHO) di China mendapat pemberitahuan tentang adanya sejenis pneumonia yang menyebabnya belum diketahui".?

Rantai penyebaran Virus Corona harus segera dihentikan. Tak hanya menjadi tanggung jawab pemerintah, masyarakat juga berperan aktif untuk menghentikan transmisi Virus Corona ini. Di Kota Langsa dalam menekan penyebaran virus corona, pemerintah Kota Langsa mengeluarkan kebijakan mengenai protokol kesehatan yang

${ }^{6}$ Sri Handayani Sagala, Yesi Maifita, Armaita, Hubungan Pengetahuan Dan Sikap Masyarakat Terhadap Covid-19: A Literature Review, Jurnal Menara Medika, Vol 3 No 1 September 2020, hlm. 51-52

${ }^{7}$ Lukman Isnawan, Pentingnya Kesadaran Masyarakat Dlaam Memutuskan Rantai Penularan Covid-19, dalam Mahasisiwa KPM IAIN Pare-Pare, Tulisan Bersama melawan Covid-19, hlm. 14 
Volume 16, Nomor 1, Januari - Juni 2021

diatur dalam Peraturan Walikota Nomor 31 Tahun 2020 tentang Penerapan Displin dan Penegakan Protokol Kesehatan. Hal itu sebagai upaya pencegahan dan pengendalian corona virus disease 2019 (Covid-9) di Kota Langsa.

Untuk sanksi pelanggaran Protokol Kesehatan (Prokes) ini dijelaskan pada Pasal 7 ayat (1) dan ayat (2) Peraturan Walikota Nomor 31 Tahun 2020 tentang Penerapan Displin dan Penegakan Protokol Kesehatan yang berbunyi :

1. bagi perorangan, pelaku usaha, pengelola, penyelenggara atau penanggungjawab tempat dan fasilitas umum yang melanggar kewajiban sebagaimana dimaksud dalam Pasal 5 dikenakan sanksi.

a. sanksi pelanggaran penerapan protokol kesehatan dalam pencegahan dan pengendalian Covid-19 sebagaimana dimaksud pada ayat (1) berupa : bagi perorangan:

1. teguran lisan atau teguran tertulis;

2. kerja sosial (membersihkan fasilitas umum atau areal publik) minimal 30 (tiga puluh) menit;atau

3. denda administratif sebesar Rp. 50.000,- (lima puluh ribu rupiah) dan/atau kerja sosial (membersihkan fasilitas umum atau area publik) minimal 60 (enam puluh) menit.

b. Bagi pelaku usaha, pengelola, penyelenggara, atau penanggung jawab tempat, dan fasilitas umum :

1. teguran lisan atau teguran tertulis untuk pelanggran pertama;

2. penghentian sementara operasional usaha selama 3 (tiga) hari atau denda administratif untuk pelanggaran kedua dengan besara denda sebesar Rp. 100.000,- (seratus ribu rupiah);

3. penghentian sementara operasional usaha selamaaa 7 (tujuh) hari atau denda administratif untuk pelanggara ketiga dengan besaran denda sebesar Rp. 100.000,- (seratus ribu rupiah); dan

4. Pencabutan izin usaha untuk pelanggaran yang keempat.

Peraturan Wali Kota Langsa ini menindaklanjuti Peraturan Gubenur Aceh Nomor 51 Tahun 2020 tentang Peningkatan Penanganan Corona Virus Disease 2019, Penerapan dan Penegakan Hukum Protokol Kesehatan di Aceh dan Instruksi Menteri Dalam Negeri Nomor 4 Tahun 2020 tentang Pedoman Teknis Penyusunan Peraturan Kepala Daerah Dalam Rangka Penerapan Disiplin dan Penegakan Hukum Protokol Kesehatan sebagai Upaya Pencegahan dan Pengendalian Corona Virus Disease 2019 di Daerah serta Instruksi Presiden Republik Indonesia Nomor 6 Tahun 2020 tentang Peningkatan Disiplin dan Penegakan Kesehatan dalam Pencegahan dan Pengendalian Corona Virus Disease 2019. 
Volume 16, Nomor 1, Januari - Juni 2021

Masyarakat Kota Langsa dalam beraktifitas harus mengurangi kontak fisik dengan orang lain, menghindari kerumunan atau keramaian, tetapi kenyataannya kesadaran mengikuti protokol kesehatan yang masih minim, dimana banyak dijumpai masyarakat yang tidak menggunakan masker, cafe-cafe masih banyak dikunjungi masyarakat yang berbincang-bincang sampai larut malam tanpa mengikuti protokol kesehatan. Dari situasi seperti ini penegakan hukum terhadap pelanggaran protokol kesehatan tidak berjalan maksimal.

Pokok permasalahan dalam pencegahan penyebaran Covid 19 di Kota Langsa ini adalah bagaimana pengaturan hukum terhadap pelanggar protokol Kesehatan dan upaya apa yang dilakukan oleh pemerintah terhadap masyarakat yang melanggar protokol Kesehatan.

Penelitian ini menggunakan metode pendekatan Yuridis Empiris, yakni penelitian hukum yang mengkaji dan menganalisis tentang perilaku hukum individua tau masyarakat dalam kaitannya dengan hukum dan sumber data yang digunakan berasal dari data primer. ${ }^{8}$ Penelitian ini menggunakan Teknik pengumpulan bahan hukum dan data yang terdiri dari Studi Kepustakaan (LiberaryResearch). Analisa bahan hukum dalam penelitian ini dilakukan dengan cara kualitatif dan disajikan secara deskriptif.

\section{Pembahasan}

\section{Pengaturan Hukum Terhadap Pelanggar Protokol Kesehatan}

Merujuk pada tulisan Muhammad Waffaa Kharisma dimana "Perkembangan penyebaran Covid 19 tejadi begitu cepat, Kasus pertama dan kedua Covid 19 diumumkan pemerintah pusat pada tanggal 2 Maret 2020 dan Kasus ketiga dan keempat diumumkan pada tanggal 6 Maret 2020. ${ }^{9}$ Pandemi Covid-19 membawa dimensi baru tidak terkira, baik kepada kehidupan manusia maupun interaksi antarnegara. Dalam perspektif hubungan international, pandemik ini seakan menajdi pelengkap bagi tren deglobalisasi sejak beberapa tahun terakhir".

Di dalam tulisan Budaya Media Sosial,Edukasi Masyarakat dan pandemi Covid-19 yang ditulis oleh Muchammad Bayu Tejo Sampurno dan dkk, mejelaskan "Coronavirus (COVID-19) adalah penyakit menular yang disebabkan oleh coronavirus versi baru yang ditemukan pada akhir 2019 lalu.4 Sebagian besar gangguan yang dialami oleh individu yang terinfeksi virus COVID-19 akan mengalami penyakit pernapasan ringan hingga sedang dan sembuh tanpa memerlukan perawatan khusus.5Prosentase penularannya lebih cenderung pada

\footnotetext{
${ }^{8}$ Salim HS dan Erlies Septiana, Penerapan Teori Hukum Pada Penelitian Tesis dan Disertasi, (Jakarta: PT. Raja Grafindo Persada, 2019), hlm. 21

${ }^{9}$ Philips Vermonte dan Teguh Yudo Wicaksono, Karakteristik dan Persebaran Covid-19 di Indonesia : Temuan Awal, dalam Indonesia dan Covid-19 Pandangan Multi Aspek dan Sektoral, CSIS Indonesia, Jakarta, Oktober 2020, hlm. 66
} 
Volume 16, Nomor 1, Januari - Juni 2021

individu usia lanjut dan mereka yangmemiliki riwayat masalah medis seperti kardiovaskular, diabetes, penyakit pernapasan kronis, dan kanker;6 di mana lebih cenderung mengembangkan infeksi virus COVID-19 menjadi penyakit yang lebih serius. $" 10$

Covid 19 tidak menimbulkan kerusakan harta benda dan sarana, prasarana tetapi menimbulkan efek ekonomi yang sangat massif, menciptakan penggangguran besar-besaran, pemberhentian dan penurunan kegiatan pedagangan sektor pariwisata dan lainnya. ${ }^{11}$ Sedangkan menurut H. Nurianto Rachmad Soepadmo "Sejak awal Maret, Pemerintah sudah diingatkan ancaman Covid-19. Namun respon pemerintah, selain hanya respon lisan, juga cenderung jauh dari professional". ${ }^{12}$

Menurut Jeki Refialdinata dalam tulisannya yang berjudul Analisis Upaya Pencegahan Covid-19 pada Masyarakat Kampus "Covid-19 dapat menular dari satu individu ke individu lainnya melalui percikan batuk/bersin (droplet). Disamping itu, orang juga dapat terinfeksi karena menyentuh permukaan yang telah terkontaminasi virus covid-19 lalu menyentuh wajah (minsalnya mata, hidung, dan mulut). Melalui penerapan physical distancingseperti menjauhi perkumpulan atau kerumunan, menghindari pertemuan masal, dan menjaga jarak dengan orang lain dapat mengurangi risiko untuk terinfeksi covid-19". ${ }^{13}$

Bertambahnya pasien Covid-19 memaksa pemerintah untuk mengambil langkah-langkah strategis penanggulangan bencana ini. Beberapa peraturanpun akhirnya ditetapkan selama masa pandemik ini. ${ }^{14}$

Pasal 4 Undang-Undang Dasar Negara Kesatuan Republik Indonesia Tahun 1945 mengatur bahwa Presiden Republik Indonesia memegang kekuasaan pemerintahan menurut Undang-Undang Dasar. Dalam melakukan kewajibannya Presiden dibantu oleh satu orang wakil Presiden. Sedangkan Pasal 12 UndangUndang Dasar Negara Kesatuan Republik Indonesia menyebutkan Presiden menyatakan keadaan bahaya. Syarat-syarat dan akibatnya keadaan bahaya ditetapkan dengan Undang-Undang. Presiden sudah menetapkan Covid-19 sebagai wabah sejak 4 Februari 2020. Hal itu dituangkan lewat Keputusan Menteri Kesehatan Republik Indonesia No.HK.01.07/MENKES/104/2020 tentang Penetapan Infeksi Novel Corona virus (Infeksi 2019-nCoV) sebagai Penyakit yang Dapat Menimbulkan

\footnotetext{
${ }^{10}$ Muchammad Bayu Tejo Sampurno, dkk, Budaya Sosial, Edukasi Masyarakat dan Pandemi Covid-19, Salam : J urnal Sosial dan Budaya Syar'l, Vol. 7, No. 6, 2020, hlm. . 529

${ }^{11}$ H.T. Ahmad Dedek, dkk, Politik Hukum, Bencana Indonesia, (Aceh: Syiah Kuala University Press, 2020), hlm. 198

12 Riant Nugroho, Kebijakan Anti Pandemi Global : Kasus Covid 19, (Jakarta: Yayasan Rumah reformasi Kebijakan Menara Sentraya Suite, 2020), hlm. 10

13 Jeki Refialdinata, Analisis Upaya Pencegahan Covid-19 pada Masyarakat Kampus, Babul Ilmi_Jurnal Multi Science Kesehatan, Volume 12, Nomor 2, Desember 2020, hlm. 59

${ }^{14}$ H. Nurianto Rachmad Soepadmo, Analisis Penyebab Meningkatnya Tindak Kriminal Selama Masa Pandemi Covid-19 di Indoensia, di dalam Buku Menyemai Benih Dharma Perspektif Multidisplin, (Sulawasi Selatan: Yayasan Ahmar Cendekia Indonesia, 2020), hlm. 83
} 
Volume 16, Nomor 1, Januari - Juni 2021

Wabah dan Upaya Penanggulangannya. Hanya saja tidak ada penetapan kedaruratan kesehatan masyarakat hingga sekarang. ${ }^{15}$

Untuk menangani penyebaran covid-19 lebih jauh dan dalam rangka menjamin kepasatian hukum, memperkuat upaya dan meningkatkan efektifitas pencegahan dan pengendalian Corona Virus Disease 2019 Covid-19 di seluruh daerah maka pemerintah Indonesia telah mengeluarkan Instruski Presiden Republik Indonesia Nomor 6 Tahun 2020 tentang Peningkatan Disiplin dan Penegakan Hukum Protokol kesehatan Dalam Pencegahan Dan Pengendalian Corona Virus Disease 2019 kemudian di teruskan dnegan dikeluarkan Instruksi Menteri Dalam Negeri Nomor 4 Tahun 2020 tentang Pedoman Teknis Penyusunan Peraturan Daerah dalam rangka Penerapan Disiplin dan penegakan Hukum Protokol Keseahtan sebagai upaya Pencegahan dan Pengendalian Corona Virus Disease 2019 di daerah. Kemudian ditindaklanjuti dengan Peraturan Gubenur Aceh Nomor 51 Tahun 2020 tentang Peningkatan Penanganan Corona Virus Disease 2019, Penerapan Disiplin dan Penegakan Hukum Protokol Kesehatan di Aceh. Sementara di Kota Langsa untuk mengatasi dan menangani meluasnya virus Corona mengeluarkan Peraturan Walikota Langsa Nomor 31 Tahun 2020 tentang Penerapan Disiplin dan Penegakan Hukum Protokol Kesehatan di Kota Langsa.

Dengan adanya peraturan perundang-undangan yang dikeluarkan oleh pemerintah, terutama di Kota Langsa instansi terkait harus menindak secara tegas msyarakat yang tidak mengikuti protokol kesehatan karena menyangkut kehidupan masyarakat yang terancam kesehatannya dengan penyebaran virus corona melalui interaksi masyarakat yang tidak diketahui terpapar virus corona dan bisa menyebabkan semakin meningkatnya penyebaran virus corona apabila masyarakat tidak mengikuti protokol kesehatan. Sanksi yang sudah diatur dalam peraturan Wali Kota di implementasikan dalam kehidupan sehari-hari sehingga kesadaran masyarakat akan bahayanya virus corona semakin meningkat.

Apabila dalam penegakan perda/peraturan kepala daerah tentang penerapan protokol kesehatan Covid-19, ditemukan adanya upaya penolakan, ketidakpatuhan atau upaya lain yang menimbulkan keresahan masyarakat dan mengganggu stabilitas kamtibmas, maka lakukan upaya penegakan hukum secara tegas terhadap siapapun oleh penegak hukum. Pasal-pasal yang menjadi acuan, yakn Pasal 212 KUHP, Pasal 214 ayat (1) dan (2) KUHP, Pasal 216 KUHP, dan Pasal 218 KUHP. Kemudian, Undang-Undang Nomor 2 Tahun 2002, Pasal 84 dan Pasal 93 UU Nomor 6 Tahun 2018 tentang Kekarantinaan Kesehatan. Adapun Pasal 212 KUHP mengatur perihal perlawanan terhadap pejabat yang sedang menjalankan tugasnya.

Pasal 212 KUHP menyebutkan : "Barang siapa dengan kekerasan atau ancaman kekerasan melawan seorang pejabat yang sedang menjalankan tugas yang

15 Masalah Hukum Penetapan Status Bencana Nasional Covid-19, https://www.hukumonline.com/berita/baca/lt5e7f1443c6534/masalah-hukum-penetapan-statusbencana-nasional-covid-19?page=3 diakses tanggal 22 Desember 2020 
Volume 16, Nomor 1, Januari - Juni 2021

sah, atau orang yang menurut kewajiban undang-undang atau atas permintaan pejabat memberi pertolongan kepadanya, diancam karena melawan pejabat, dengan pidana penjara paling lama satu tahun empat bulan atau pidana denda paling banyak empat ribu lima ratus rupiah".

Dari pasal diatas dapat dijelaskan bahwa supaya dapat dihukum maka harus:

a. Melakukan perlawanan memakai kekerasan atau ancaman kekerasan

b. Perlawanan itu dilakukan terhadap pegawai negeri sipil yang sedang menjalankan tugasnya yang syah, atau terhadap orang (tidak perlu pegawai negeri) yang membantunya dalam atugas itu.

c. Prang yang melawan harus mengetahui, bahwa ia melawan kepada pegawai negeri (sifat pegawai negeri ini biasanya dapat diketahui dari pakaian seragamnya, atau sesudah memperlihatkan tanda-tanda atau surat legitimasi), tetapi tidak perlu bahwa orang itu mengetahui tentang pegawai negeri itu sedang bekerja dalam melakukan pekerjaan jabatan yang sah. ${ }^{16}$

Sedangkan Pasal 214 KUHP menyebutkan :

(1) Paksaan dan perlawanan berdasarkan pasal 211 dan 212 jika dilakukan oleh dua orang atau lehih dengan bersekutu, diancam dengan pidana penjara paling lama tujuh tahun.

(2) Yang bersalah dikenakan: 1. pidana penjara paling lama delapan tahun enam bulan, jika kejahatan atau perbuatan lainnya ketika itu mengakibatkan lukaluka; 2. pidana penjara paling lama dua belas tahun, jika mengakibatkan luka berat; 3. pidana penjara paling lama lima helas tahun, jika mengakibatkan orang mati.

Pasal diatas dapat dijelaskan bahwa kejahatan dalam Pasal 211 dn 212 diancam hukuman yang lebih berat, apabila dilakukan oleh dua orang Bersama-sama atau lebih, dan ancaman hukumannya berturut-turut ditambah lagi, apabila ini menimbulkan pula akibat-akibat sebagaimana tersebut pada sub 1 s.d. 3 ayat (2) dari pasal ini

Pasal 216 KUHP menyebutkan :

(1) Barang siapa dengan sengaja tidak menuruti perintah atau permintaan yang dilakukan menurut undang-undang oleh pejabat yang tugasnya mengawasi sesuatu, atau oleh pejabat berdasarkan tugasnya, demikian pula yang diberi kuasa untuk mengusut atau memeriksa tindak pidana; demikian pula barang siapa dengan sengaja mencegah, menghalang-halangi atau menggagalkan tindakan guna menjalankan ketentuan undang- undang yang dilakukan oleh salah seorang pejabat tersebut, diancam dengan pidana penjara paling lama

${ }^{16}$ Ibid., hlm. .168 
Volume 16, Nomor 1, Januari - Juni 2021

empat bulan dua minggu atau pidana denda puling banyak sembilan ribu rupiah.

(2) Disamakan dengan pejahat tersebut di atas, setiap orang yang menurut ketentuan undang-undang terus-menerus atau untuk sementara waktu diserahi tugas menjalankan jabatan umum.

(3) Jika pada waktu melakukan kejahatan belum lewat dua tahun sejak adanya pemidanaan yang menjadi tetap karena kejahatan semacam itu juga, maka pidananya dapat ditambah sepertiga.

Pasal diatas dapat dikelaskan bahwa yang diancam hukuman dalam pasal ini ialah dengan sengaja tidak mentaati perintah atau tuntutan pegawai negeri. Perintah atau tuntutan itu harus dilakukan berdasarkan atas suatu peraturan perundangundangan, jika tidak dapat dihukum menurut pasal ini. Supaya dapat dihukum tidak sembarangan pegawai negeri, akan tetapi perintah atau tuntutan itu harus dilakukan pleh pegawai negeri yang diwajibkan mengawasi atau diwajibkan untuk menyelidiki atau memeriksa perbuatan yang dapat dihukum. Dalam pasal ini diancam hukuman pula orang yang sengaja, mencegah, merintangi atau mengagalkan suatu perbuatan yang dilakukan oleh pegawai negeri tersebut di atas yang selenggarakan menurut peraturan undang-undang. ${ }^{17}$

Sementara Pasal 218 KUHP menyebutkan "Barang siapa pada waktu rakyat datang berkerumun dengan sengaja tidak segera pergi setelah diperintah tiga kali oleh atau atas nama penguasa yang berwenang, diancam karena ikut serta perkelompokan dengan pidana penjara paling lama empat bulan dua minggu atau pidana denda paling banyak sembilan ribu rupiah.

Dalam pasal ini dijelaskan waktu orang-orang berkerumun sama dengan orang-orang berkerumun yang mengacau (volksoplop), jadi bukan orang-orang berkerumun yang tenteram dan damai yang biasanya segera semua pergi, jika diperintahkan supaya bubar Diperintahkan tiga kali : perintah itu harus dengan suara keras sehingga dapat didengar oleh orang-orang itu. ${ }^{18}$

Pasal 84 UU Nomor 6 Tahun 2018 tentang Kekarantinaan Kesehatan berbunyi "Selain penyidik pejabat Kepolisian Negara Republik Indonesia, pejabat pegawai negeri sipil tertentu di lingkungan kementerian yang menyelenggarakan urusan pemerintahan di bidang kesehatan diberi wewenang khusus sebagai penyidik sebagaimana dimaksud dalam Undang-Undang yang mengatur mengenai hukum acara pidana untuk melakukan penyidikan tindak pidana di bidang Kekarantinaan Kesehatan".

Pasal 93 Undang-Undang Nomor 6 Tahun 2018 tentang Kekarantinaan Kesehatan menyebutkan "Setiap orang yang tidak mematuhi penyelenggaraan

${ }^{17}$ Ibid., hlm. 171-172

${ }^{18}$ Ibid., hlm. 172 
Volume 16, Nomor 1, Januari - Juni 2021

Kekarantinaan Kesehatan sebagaimana dimaksud dalam Pasal 9 ayat (1) dan/atau menghalang-halangi penyelenggaraan Kekarantinaan Kesehatan sehingga menyebabkan Kedaruratan Kesehatan Masyarakat dipidana dengan pidana penjara paling lama 1 (satu) tahun dan/atau pidana denda paling banyak Rp100.000.000,00 (seratus juta rupiah)".

Tindakan tegas harus dilakukan oleh penegak hukum bagi pelanggar protokol Kesehatan yang telah ditetapkan. Apabila dalam kebijakan Walikota tidak bisa dilaksanakan dengan penerapan sanksi-sanksi yang diatur dalam Peraturan Walikota Langsa Nomor 31 Tahun 2020 tentang Penerapan Disiplin dan Penegakan Hukum Protokol Kesehatan di Kota Langsa, maka penegak hukum dapat dilaksanakan dengan menggunakan Kitab Undang-Undang Hukum Pidana yang tercantum dalam Pasal-Pasal yang sudah disebutkan diatas, dan Undang-Undang yang lain terkait pencegahan penyebaran Covid 19, sehingga masyarakat jera dan mamatuhi protokol Kesehatan demi kehidupan masyarakat Kota Langsa.

Kitab Undang-Undang Hukum Pidana mempunyai sanksi yang tegas yang penerapannya bisa dilakukan upaya paksa oleh penegak hukum dan selanjutnya diproses berdasarkan hukum acara pidana. Sementara Peraturan Walikota Langsa Nomor 31 Tahun 2020 tentang Penerapan Disiplin dan Penegakan Hukum Protokol Kesehatan di Kota Langsa mengenai penerapan sanksinya hanya berupa teguran, kerja social dan denda administratif, sehingga dengan sanksi tersebut masih banyak masyarakat yang mengabaikannya karena Sebagian masyarakat yang tidak disiplin sanksi tersebut tidak berat.

\section{Upaya Pemerintah Terhadap pelanggar Protokol Kesehatan}

Pemerintah memiliki tanggung jawab untuk berperan penuh mencarikan alternatif jalan keluar terhadap penyebaran virus Covid 19. Kesehatan masyarakat adalah salah satu hak yang dijamin secara konstitusional. ${ }^{19}$ Secara normatif, Indonesia telah meratifikasi Deklarasi Universal Hak Asasi Manusia (Duham), Konvenan Internasional tentang Hak Sipil dan Politik, dan Konvenan Internasional tentang Hak Ekonomi, Sosial, dan Budaya (Ekosob), menjadi UU Nomor 11 Tahun 2005 serta UU Nomor 12 Tahun 2005.

Dalam Pasal 12 Konvenan Hak Ekosob, salah satu ketentuannya juga menyatakan bahwa negara pihak harus melakukan segala sesuatu yang diperlukan untuk mengupayakan: Pencegahan, pengobatan, dan pengendalian segala penyakit menular, endemik, penyakit lainnya yang berhubungan dengan pekerjaan.Jadi,

19 Satria Unggul Wicaksana, et. All, Dinamika Perlindungan HAM bagi Kaum Masyarakat Marginal Pasca Pandemi Covid di Era Society 5.Odi Era, (Surabaya: UMSurabaya Publishing, 2021), hlm. 167 
kesehatan sangatlah penting karena dia menjadi prasyarat bagi seseorang untuk dapat maksimal mencapai harkat hidupnya, ${ }^{20}$

Wabah virus korona yang menyebar dengan sangat cepat ke seluruh tanah air. Hal ini mendorong pemerintah Indonesia untuk melakukan upaya dan mengambil kebijakan penanganan virus corona. Salah satu upaya awal yang dilakukan untuk pencegahan virus corona adalah mengeluarkan kebijakan tentang penerapan protokol Kesehatan agar dapat dilaksanakan oleh masyarakat.

Muhammad Waffaa Kharisma menambahkan lagi dalam tulisannya bahwa "Covid 19 menimbulkan pembatasan yang sangat ketat terhadap kebebasan manusia di satu sisi dan adanya penolakan pembatasan kebebasan kebebasan di sisi lain oleh Negara. Disela perlawanan inilah peran hukum untuk melegalkan pembatalan demi kemaslahatan umum sangat dibutuhkan".

Dalam masa Covid-19 ini juga banyak sekali penyebar berita, data atau informasi bohong terkait dengan Covid 29. Setiap upaya penanganan, perlu penegakan hukum yang tegas terhadap para pelaku. Kerugian yang diakibatkan oleh berita bohong atau hoaks ini akan jauh lebih berbahaya ketimbang Covid 19 itu sendiri jika diabaikan. Sudang Barang tentu di tengah situasi sulit seperti sekarang, ada saja pihak-pihak yang ingin membuat situasi semakin meresahkan dan mengambil keuntungan darinya. ${ }^{22}$

Bertambahnya pasien positif Covid-19 memaksa pemerintah untuk mengambil langkah-langkah strategis penanggulangan bencana ini. Beberapa peraturanpun akhirnya ditetapkan salama masa pandemik ini. Pandemi ini membawa dampak yang sangat signifikan bagi kelangsungan hidup umat manusia di dunia. ${ }^{23}$

Tidak disiplinnya masyarkat mematuhi protokol kesehatan dapat dilihat dari berbagai faktor meliputi faktor pendidikan dan pemahamanan masyarakat yang rendah dan menganggap remeh covid-19, Faktor dari dalam diri meliputi percaya pada takdir tanpa mau berusaha menjaga diri atau menjaga kesehatan, faktor tekanan ekonomi yang mengakibatkan tetap harus bekerja tanpa memperdulikan protokol kesehatan, ketidakpercayaan terhadap kebijakan pemerintah, lemahnya instrumen hukum dan kurang tegasnya pemerintah dalam penerapan sanksi terhadap pihak yang tidak mematuhi protokol kesehatan. ${ }^{24}$

20 Despan Heryansyah, Wabah Corona dan Tanggung Jawab Negara diakses https://news.detik.com/kolom/d-4942715/wabah-corona-dan-tanggung-jawab-negara tanggal 4 Mei 2021

${ }^{21}$ Muhammad Waffaa Kharisma, Op. Cit.,

${ }^{22}$ Ibid.,

${ }^{23}$ H. Nurianto Rachmad Soepadmo, Op .Cit., hlm. 83

${ }^{24}$ Citranu, Pencegahan Prinsip Hukum Adat Dayat Terkait Pencegahan Covid-19 di Masa New Normal dalam Menyemai Benih Darma Perspektif Multidisplin, (Sulawesi Selatan: Yayasan Ahmar Cendekia Indonesia, 2020), hlm. 4 
Volume 16, Nomor 1, Januari - Juni 2021

Pemerintah dalam hal ini dilema atau serba salah dalam mengambil kebijakan antara penegekan hukum kesehatan atau penyelamatan ekonomi, sehingga pemerintah mengambil jalan tengah untuk tetap memberlakukan keadaan new normal dengan catatan wajib mematuhi prottokol kesehatan seharusnya memberikan sanksi tegas sehingga menjadi presedent bagi seluruh masyarakat untuk tetap taat terhadap hukum dan protocol kesehatan, sehingga bisa menekan penyebaran virus Covid-19 selama anti virus masih dalam pengembangan oleh pemerintah. ${ }^{25}$

New normal (adaptasi kebiasaan baru) dapat diartikan sebagai tatanan kehidupan baru dimana sesuatu yang tidak biasa dilakukan dsebelumnya menjadi normal untuk dilakukan. Dalam kaitannya dengan pandemic Covid-19 diartikan sebagai perubahan perilaku masyarakat yang akan memperngaruhi kegiatan seharihari masyarakat. Tim Pakar Gugus Tugas Percepatan Penanganan Covid-19 mendefinisikan yang dapat dijabarkan sebagai perubahan perilaku untuk tetap mejalankan aktifitas normal namun dengan ditambah nenerapkan masker, menjaga jara dan menjaga kebersihan tangan guna mencegah terjadinya penularan Covid-19 selama beraktivitas secara normal baru. ${ }^{26}$

Dampak yang terjadi di Kota Langsa terjadi baik dalam bidang sosial, ekonomi, kesehatan, hukum dan bidang lainnya. Dengan adanya pandemi ini membuat perubahan pada pola hidup di masyarakat. Diberlakukannya pembatasan kegiatan dan interaksi di luar rumah, tetap masyarakat menjalankan kegiatannya untuk mempertahankan hidup, penegak hukum dalam menerapkan kebijakan bagi pelanggar protokol kesehatanpun tidak bisa membendung kegiatan masyarakat, Di dalam menangani wabah yang melanda ini, penegakan hukum menjadi salah satu langkah yang dipilih oleh pemerintah khususnya di Kota Langsa. Pemerinta Kota Langsa telah membentuk tim di dalam menangani penyebaran lebih jauh virus corona ini dimana tim tersebut di pimpin langsung oleh walikota langsa dengan melakukan upaya menghimbau dan terus melakukan sosialisasi akan bahayanya virus corona yang sekarang masyarakat sudah tidak merasa khawatir lagi dan menerapkan secara tegas saksi bagi pelanggar protokol kesehatan.

Tim bekerja dengan Pihak-pihak terkait dikerahkan dalam mengatasi wabah virus corona. Secara garis besar polisi disini bertugas dalam membubarkan kerumunan massa, menangani penyebar berita bohong atau hoaks. Oleh karena itu pemerintah kota langsa selalu menekan bahwa masyarakat harus memilah mana yang benar mana yang tidak benar atau berita bohong/hoaks. Pemerintah juga meminta agar warga masyarakat agar tidak panik dalam menghadapi virus corona di masa sekarang. Karena wabah ini adalah wabah yang bisa menginfeksi siapapun terutama bagi mereka dalam kategori rentan terinfeksi seperti anak-anak dan orang lanjut usia atau mereka dengan imunitas rendah

25 Ibid.,

26 Andika Chandra, dkk, Seri 3 Covid-19 dan New Normal Informasi Yang Harus Diketahui Seputar Coronavirus, Quepedia, 2020, hlm. 13 


\section{Penutup}

Pengaturan hukum terhadap pelanggaran protokol kesehatan terakomodir dalam berbagai peraturan perundang-undangan, sampai tingkat kabupaten dan kota, kebijakan terhadap pencegahan penyebaran covid dilakukan oleh pemerintah seperti Peraturan Walikota Langsa Nomor 31 Tahun 2020 tentang Penerapan Displin dan Penegakan Protokol Kesehatan, dengan mengeluarkan peraturan walikota untuk mengantisipasi penyeberan virus corona yaitu dengan memberikan sanksi kepada masyarakat yang melanggar protokol kesehatan.

Pelanggaran terhadap protokol kesehatan banyak diabaikan oleh masyarakat karena masyarakat sudah tidak khawatir lagi dengan virus corona tetapi upaya pencegahan penyebaran virus corona tetap dilakukan oleh pemerintah karena fakta bahwa virus itu semakin hari semakin meningkat jumlah orang yang terpapar, pemerintah Kota Langsa tetap menghimbau dan melakukan sosialisasi bahayanya virus corona dengan menggugah kesadaran masyarakat untuk tetap mengikuti protokol kesehatan dalam menjalankan aktifitasnya.

\section{Daftar Pustaka}

Andika Chandra, dkk, Seri 3 Covid-19 dan New Normal Informasi Yang Harus Diketahui Seputar Coronavirus, Quepedia, 2020

Citranu, Pencegahan Prinsip Hukum Adat Dayat Terkait Pencegahan Covid-19 di Masa New Normal dalam Menyemai Benih Darma Perspektif Multidisplin, Yayasan Ahmar Cendekia Indonesia, Sulawesi Selatan, 2020

Despan Heryansyah, Wabah Corona dan Tanggung Jawab Negara diakses https://news.detik.com/kolom/d-4942715/wabah-corona-dan-tanggung-jawabnegara tanggal 4 Mei 2021

H. Nurianto Rachmad Soepadmo, Analisis Penyebab Meningkatnya Tindak Kriminal Selama Masa Pandemi Covid-19 di Indoensia, di dalam Buku Menyemai Benih Dharma Perspektif Multidisplin, Yayasan Ahmar Cendekia Indonesia, Sulawasi Selatan, 2020

H.T. Ahmad Dedek, dkk, Politik Hukum, Bencana Indonesia, Syiah Kuala University Press, Aceh, 2020

Jeki Refialdinata, Analisis Upaya Pencegahan Covid-19 pada Masyarakat Kampus, Babul Ilmi_Jurnal Multi Science Kesehatan, Volume 12, Nomor 2, Desember 2020 
Volume 16, Nomor 1, Januari - Juni 2021

Jimly Asshiddiqie, Penegakan Hukum, diakses www.jimly.com/makalah/namafile/56/ Penegakan_Hukum.pdf Laurensius Arliman S, Penegakan Hukum dan Kesadaran Masyarakat, Deepublsih, Yogyakarta, 2015

Lukman Isnawan, Pentingnya Kesadaran Masyarakat Dlaam Memutuskan Rantai Penularan Covid-19, dalam Mahasisiwa KPM IAIN Pare-Pare, Tulisan Bersama melawan Covid-19

Masalah Hukum Penetapan Status Bencana Nasional Covid-19, https://www.hukumonline.com/berita/baca/lt5e7f1443c6534/masalah-hukumpenetapan-status-bencana-nasional-covid-19?page $=3$ diakses tanggal 22 Desember 2020

Muchammad Bayu Tejo Sampurno, dkk, Budaya Sosial, Edukasi Masyarakat dan Pandemi Covid-19, Salam : J urnal Sosial dan Budaya Syar'I, Vol. 7, No. 6, 2020

Muhammad Waffaa Kharisma, Dunia di tengah Pandemi Covid-19 : Perspektif Geopolitik, dalam dalam Indonesia dan Covid-19 Pandangan Multi Aspek dan Sektoral, CSIS Indonesia, Jakarta, Oktober 2020

Philips Vermonte dan Teguh Yudo Wicaksono, Karakteristik dan Persebaran Covid-19 di Indonesia : Temuan Awal, dalam Indonesia dan Covid-19 Pandangan Multi Aspek dan Sektoral, CSIS Indonesia, Jakarta, Oktober 2020

R. Soesilo, Kitab Undang-Undang Hukum Pidana (KUHP) Serta KomentarKomentarnya Lengkap Pasal Demi Pasal, Politea, Bogor, 1994

Riant Nugroho, Kebijakan Anti Pandemi Global : Kasus Covid 19, Yayasan Rumah reformasi Kebijakan Menara Sentraya Suite, Jakarta, 2020

Salim HS dan Erlies Septiana, Penerapan Teori Hukum Pada Penelitian Tesis dan Disertasi, PT. RajaGrafindo Persada, Jakarta, 2019

Sanyoto, Penegakan Hukum di Indonesia, Jurnal Dinamika Hukum, Vol. 8 No. 3 September 2008

Satria Unggul Wicaksana, et. All, Dinamika Perlindungan HAM bagi Kaum Masyarakat Marginal Pasca Pandemi Covid di Era Society 5.Odi Era, UMSurabaya Publishing, Surabaya, 2021

Sri Handayani Sagala, Yesi Maifita, Armaita, Hubungan Pengetahuan Dan Sikap Masyarakat Terhadap Covid-19: A Literature Review, Jurnal Menara Medika, Vol 3 No 1 September 2020 